\title{
A Study on Awareness of Social Rights and Privileges for Women among the Female Understudy Educators
}

\author{
Vinnaras Nithyanantham ${ }^{1} \&$ Rekha $\mathrm{N}^{2}$
}

\begin{tabular}{l} 
ARTICLE INFO \\
\hline Article History: \\
Received 01.12.2018 \\
Received in revised form \\
08.02.2019 \\
Accepted \\
Available online 01.07 .2019
\end{tabular}

\begin{abstract}
The aim of the current study is to determine on awareness of social rights and privileges for women among the Female Understudy Educators. The Indian Constitution has sanctioned the State to implement measures in fav or of wo men for nullify ing the collectiv e socio-economic, educational and political shortcomings faced by them. Anti-social activities against women: dowry, sexual harassment and other deaths are recorded each day in Indian newspapers, according to the national crimes statistics bureau. Who will become the instruments for justice? It is none but the teachers, the women teachers. To instill proper values and to bring awareness to the younger generation, the teachers must be sensitized at first. The wo men who aspire for teaching profession must get proper knowledge, understanding and awareness regarding rights and privileges of Indian women. So, the investigator initiated to the presentstudy on awareness of Female Understudy Educators regarding rights and privileges for women. The sample for study is selected from Female Understudy Educators in Chennai city Teacher Training Educational Institutions. The sample counted in Female Understudy Educators selected randomly from B.Ed Integrated and B.Ed Normal courses. From the present study the investigators could infer that, the Female Understudy Educators need more awareness related to personal, familial and social life. Even though there was moderate and high level of awareness for 92 per cent of the sample, eight per cent of the sample had low level of awareness. If the present trainees or the future teachers get awareness on social issues, they can impart this awareness to all the female students. It is essential that every citizen of India, especially every woman must have awareness about the constitutional and legal rights.
\end{abstract}

C) IJERE. All rights resenved

Keywords: ${ }^{1}$

Teaching community, Social Rights, B.Ed Integrated and B.Ed Normal, Female Understudy Educators.

\section{INTRODUCTION}

The Indian Constitution has not only given guarantees for equality to women but also sanctions the State to implement measures in favor of women for nullifying the collective socio-economic, educational and political shortcomings faced by them(Government of India 2001a). Fundamental Rights, among others confirms equality before the law, equal security of law, excludes discernment in contradiction of any citizen on grounds of religion, race, caste, sex or place of birth, and assurances equality of opportunity to all citizens in problems relating to employment, articles 14, 15, 15(3), 39(a), 39(b), 39(c) and 42 of the constitution are explicit reputation in this regard (Agnes Folia, 1992). Anti-social activities against women: dowry, sexual harassment and other deaths are recorded each day in Indian new spapers, according to the national crimes statistics bureau (Aggarwal, Bina. 1985). Times of India report 2015 said every year 25 per cent wives are sexually harassed by their own husbands. Every year 44 per cent of the unmarried young women are subjected to sexual violence. Every year 14 per cent of the schools going girl children are molested by their teachers. It is saddening to note that women have a 40 per cent involvement in abetting or allowing these atrocities (C.S.I. Board for women's work, 2014). Who will root out the causes which promote these atrocities? Who will weed out these atrocities? Who will become the instruments for justice? It is none but the teachers, the women teachers. To instill proper values and to bring awareness to the younger generation, the teachers must be sensitized at first (Shahnaj Parveen, 2007). The women who aspire for teaching profession must get proper knowledge, understanding and awareness regarding rights and privileges of Indian women (Naseema, C. 2008). So, the present investigators intended to study the aw areness of Female Understudy Educators regarding rights and privileges for women. 


\section{Significance of the study}

In India, women are the sources of culture and tradition but they are not in existent safety of their everyday life. Now a days many of the women coming out from the family for going to school, college, offices and for every day jobs in all the fields (Aggarwal, Bina. 1985). Even though they are imbedded socially, emotionally, economical and sexually in every places that news's are coming in all Media daily. There are many social rights and privileges are available in our country but the aw areness are very poor among the women (Addissie Melak \& Dr. Seema Singh, 2018). Mostly the teachers or the literate people should give proper aw areness among the female in schools and colleges. This study was investigated among the understudy educates in Teacher Training Educational Institutions in Chennai city. At present, this program is available in two types like Four years integrated (After Higher secondary they have to join and study degree with teacher training four years) and Two years Normal (After completion of UG or PG they can study this two years Teacher Training). Teachers are the source of knowledge they can reach all aspect of life to the society. In this study investigator study about the Awareness on Social Rights and Privileges for Women among the Female Understudy Educators in both type of groups to get the social awareness of women among the would be teachers.

\section{Statement of the problem:}

The investigator has investigated a study on the Awareness of Social Rights and Privileges for Women among the Female Understudy Educators as a statement of the problem.

\section{Objectives of the study:}

1. To find out the difference in the level of aw areness of Female Understudy Educators.

2. To study the level of awareness of social rights and privileges for women of Female Understudy Educators about

a. Locality (Rural / Urban)

b. Types of Training B.Ed Integrated and B.Ed Normal

c. Parent's Educational status (Educated / Uneducated)

\section{Hypothesis of the study}

1. There is no significant difference between the mean scores of Female Understudy Educators with respect to area of residence (Locality) on their aw areness regarding their social rights and privileges.

2. There is no significant difference between the mean scores of Female Understudy Educators of different type of training on their aw areness regarding their social rights and privileges.

3. There is no significant difference between the mean scores of Female Understudy Educators with parents of different educational status on their awareness regarding their social rights and privileges.

\section{Sample for the study}

The sample for study is selected from Female Understudy Educators in Chennai city Teacher Training Educational Institutions. The sample counted in Female Understudy Educators selected randomly from B.Ed Integrated and B.Ed Normal courses. In Teacher training courses majority of the students are female and the B.Ed Integrated courses students are joining after their higher secondary Education at 18 to 19 years of age, but in B.Ed Normal courses students arejoining after their Graduations (UG or PG) at 22 and above years of age. The total sample were 70 Female trainees from B.Ed Integrated and 90 Female trainees from B.Ed Normal course. In total there were 160 respondents. 


\section{Tools for this study}

The investigators framed a questionnaire about the personal and familial rights, rights regarding work place and social rights and privileges as a tool for this study. The tool comprised two parts. Part 1 deals with the variables related to personal data. The second part is with three sub divisions as mentioned earlier. This part has 78 questions related to rights and privileges of women. There are 37 questions regarding personal and familial Rights and privileges. 18 under work place and 23 under the social category. The questionnaire is a three point scale Yes, Someone and No. There are 61 positive 17 negative items. The scores are 3, 2, 1 and1, 2, 3 for positive and negative items respectively. The validity of the tool is established and the reliability value is 0.7 .

Analysis, interpretation and findings

Table 1

LEVEL OF AWARENESS OF WOMEN TEACHER TRAINEE

\begin{tabular}{|c|c|c|c|}
\hline S.NO. & $\begin{array}{c}\text { LEVEL OF } \\
\text { AWARENESS }\end{array}$ & NUMBER & PERCENTAGE \\
\hline 1 & LOW & 13 & $8.12 \%$ \\
\hline 2 & MODERATE & 62 & $38.75 \%$ \\
\hline 3 & HIGH & 85 & $53.13 \%$ \\
\hline \multicolumn{2}{|c|}{ TOTAL } & 160 & $100.00 \%$ \\
\hline
\end{tabular}

The above table illustrates the three levels of awareness of Female Understudy Educators regarding the rights of women. More than half of the sample had high level of awareness, less than one tenth of the sample had low level of aw areness and the remaining sample had moderate level of aw areness. From the analysis the investigators found that only a meager section of the sample had low level of aw areness. It is a good indicator for the development of our nation. It also indicates the necessity to create aw areness to all Female Understudy Educators because the present trainees are the future teachers who have to mold the future students.

Table 2

AWARENESS OF FEMALE UNDERSTUDY EDUCATORS WITH RESPECT TO LOCALITY

\begin{tabular}{|c|c|c|c|c|c|c|}
\hline $\begin{array}{l}\text { Variabl } \\
\text { e }\end{array}$ & $\begin{array}{l}\text { Loc } \\
\text { ality }\end{array}$ & $\begin{array}{l}\text { Num } \\
\text { ber }\end{array}$ & Mean & SD & $\begin{array}{l}\text { C.R. } \\
\text { Value }\end{array}$ & $\begin{array}{c}\text { Rema } \\
\text { rks } \\
\text { at } \\
0.05 \text { level }\end{array}$ \\
\hline $\begin{array}{l}\text { Personal } \\
\text { And }\end{array}$ & Rural & 92 & 86.1413 & 10.7558 & 1.1308 & NS \\
\hline Family & $\begin{array}{l}\text { Urban } \\
\text { Rural }\end{array}$ & $\begin{array}{l}68 \\
92\end{array}$ & $\begin{array}{l}88.2500 \\
40.5761\end{array}$ & $\begin{array}{c}12.2863 \\
6.4256\end{array}$ & & \\
\hline Work Place & $\begin{array}{l}\text { Urban } \\
\text { Rural }\end{array}$ & $\begin{array}{l}68 \\
92\end{array}$ & $\begin{array}{l}40.7500 \\
52.1957\end{array}$ & $\begin{array}{l}7.2404 \\
8.7343\end{array}$ & 0.1575 & NS \\
\hline Social & $\begin{array}{l}\text { Urban } \\
\text { Rural }\end{array}$ & $\begin{array}{l}68 \\
92\end{array}$ & $\begin{array}{c}54.9559 \\
178.8152\end{array}$ & $\begin{array}{c}7.4032 \\
21.6805\end{array}$ & 2.1585 & $S$ \\
\hline Total & Urban & 68 & 183.6912 & 22.4514 & 1.3779 & NS \\
\hline
\end{tabular}


From the above table it is exposed that the rural Female Understudy Educators had more aw areness regarding the social rights and privileges of women. Both the rural and urban respondents had no significant difference in their awareness regarding the rights and privileges related to personal/ family and work place.

On the whole there was no significant difference in their aw areness on rights and privileges with respect to locality. So the null hypothesis $1 \mathrm{w}$ as accepted. The rural Female Understudy Educat ors had more awareness than the urban Female Understudy Educators. This might be due to the factors that in rural India, still there is prevalence of violence against women, harassment, child marriage, problem in education for girls etc. At the same time the self-help groups' and NGO's activities are more in rural India to uplift them and that in turn bring more social aw areness.

Table 3

AWARENESS OF FEMALE UNDERSTUDY EDUCATORS WITH RESPECT TO TYPE OF TEACHER TRAINING

\begin{tabular}{|c|c|c|c|c|c|c|}
\hline Variable & $\begin{array}{c}\text { Type of } \\
\text { Teacher Training }\end{array}$ & $\begin{array}{l}\mathrm{Nu} \\
\text { mber }\end{array}$ & Mean & SD & $\begin{array}{l}\text { C. } \\
\text { R. }_{\text {Va }}^{\text {Va }} \\
\text { lue }\end{array}$ & $\begin{array}{c}\text { Rem } \\
\text { arks } \\
\text { at } \\
0.05 \text { level } \\
\end{array}$ \\
\hline Personal & B.Ed Integrated & 70 & 84.1714 & 12.1043 & & \\
\hline And & & & & & 2.8034 & S \\
\hline \multirow[t]{2}{*}{ Family } & B.Ed Normal & 90 & 89.2667 & 10.4369 & & \\
\hline & B.Ed Integrated & 70 & 40.9000 & 6.3542 & & \\
\hline \multirow[t]{3}{*}{ Work Place } & & & & & 0.4170 & NS \\
\hline & B.Ed Normal & 90 & 40.4556 & 7.0949 & & \\
\hline & B.Ed Integrated & 70 & 50.8286 & 9.0348 & & \\
\hline \multirow[t]{3}{*}{ Social } & & & & & 3.4384 & $S$ \\
\hline & B.Ed Normal & 90 & 55.3444 & 7.0917 & & \\
\hline & B.Ed Integrated & 70 & 175.9000 & 23.4284 & & \\
\hline \multirow[t]{2}{*}{ Total } & & & & & 2.5179 & S \\
\hline & B.Ed Normal & 90 & 184.7667 & 20.2573 & & \\
\hline
\end{tabular}

The above table shows that the B.Ed Integrated and B.Ed Normal Female Understudy Educators had more aw areness regarding the personal/familial and social rights and privileges of women than others.. B.Ed Integrated and B.Ed Normal respondents had no significant difference in their aw areness regarding the rights and privileges related to work place. In total there was a significant difference in their aw areness on rights and privileges with respect to type of teacher training. So the null hypothesis $2 \mathrm{w}$ as rejected. The reason for this finding might be that the B.Ed Integrated Female Understudy Educators, entered into the training programme as soon as they had passed secondary education and also there was an age limit for them. But the B.Ed Normal Female Understudy Educators had no age limit and they entered into the training programme after they had finished UG or PG courses and the long duration of study before the training course might had influenced them to know more about their rights in the family and society. 
TABLE 4

AWARENESS OF FEMALE UNDERSTUDY EDUCATORS WITH RESPECT TO PARENT'S EDUCATIONAL STATUS

\begin{tabular}{|c|c|c|c|c|c|c|}
\hline Variable & $\begin{array}{l}\text { Educational } \\
\text { Status }\end{array}$ & $\begin{array}{l}\text { Numb } \\
\text { er }\end{array}$ & Mean & SD & $\begin{array}{l}\text { C.R. } \\
\text { Valu } \\
\text { e }\end{array}$ & $\begin{array}{c}\text { Rema } \\
\text { rks } \\
\text { at } \\
0.05 \text { level }\end{array}$ \\
\hline Personal & Illiterate & 34 & 83.2647 & 12.2889 & & \\
\hline And & & & & & 2.0602 & Sig \\
\hline Family & Literate & 126 & 88.0556 & 11.0312 & & \\
\hline \multirow{3}{*}{ Work Place } & Illiterate & 34 & 40.1176 & 6.2108 & \multirow[b]{2}{*}{0.5492} & \multirow{3}{*}{ N.S. } \\
\hline & Literate & 126 & 40.7937 & 6.9240 & & \\
\hline & Illiterate & 34 & 49.9412 & 9.1585 & \multirow{3}{*}{2.5337} & \\
\hline \multirow[t]{3}{*}{ Social } & & & & & & \multirow[t]{2}{*}{ Sig } \\
\hline & Literate & 126 & 54.2937 & 7.8093 & & \\
\hline & Illiterate & 34 & 173.3235 & 24.6502 & \multirow{3}{*}{2.0784} & \multirow{3}{*}{ Sig } \\
\hline \multirow[t]{2}{*}{ Total } & & & & & & \\
\hline & Literate & 126 & 182.9286 & 20.9535 & & \\
\hline
\end{tabular}

From the above table it is revealed that there was no significant difference between the Female Understudy Educators who have parent's educational status illiterate or literate, in their awareness regarding the rights in work place. But there was significant difference in the mean scores of other dimensions. In total, there was significant difference in their aw areness of rights and privileges for women with respect to their parents' educational status. So the null hy pothesis $3 \mathrm{w}$ as rejected. The literate parents influenced their daughters to have more aw areness regarding personal, familial and social rights.

\section{Findings:}

From the present study the investigators could infer that, the Female Understudy Educators need more aw areness related to personal, familial and social life. Even though there w as moderate and high level of aw areness for 92 per cent of the sample, eight per cent of the sample had low level of awareness. In the "man making process" the teachers should have adequate knowledge regarding the constitutional laws of the county, as "Ignorance of law is not excused". So at the time of admission to teacher training course a general constitutional awareness test may be given to identify the level of awareness of rights and responsibilities. The students who possess the minimum level of aw areness may be given special exposure. To ensure legal rights awareness it should be included in the teacher training syllabus. Legal literacy program for student teachers should be started. This will help to improve the teacher trainees overall performance. And also the Parents should be aware of these rights to give the awar eness of their female children. Most of the family members are using the networking technology, they could be shared the everyday news and women agitations and discussed with their children that makes more aw areness among them. It also helps to control the legal ignorance and legal illiteracy and strengthens the educational process 
in attaining its main objective. Social, Political, Cultural and Ethical concerns are equally important for human engineers as academic skills.

\section{Educational implication and Conclusion:}

Education is an important tool for emancipation. It liberates the individuals from ignorance, leads to all round development of the learners. The development of individuals contributes to national development. The human engineers have the responsibility of shaping the students to adapt with the ever changing environment and to ensure social harmony. So the teachers should have adequate and proper knowledge, understanding, attitude and application skill tow ards various issues in society. As the role of teachers is multidimensional, they should have awareness of the legal rights and their implications. The women teachers should have aw areness about the rights and privileges of women in Indian society, because women's rights are human rights. They must feel that it is important to fight for this human right. Women have a key role to play in family, society and for national development. Apart from several other means such as media, which are used for creating aw areness, the teaching community which is at the root level is the best means of creating aw areness on legal rights of women, their level of aw areness is more essential for the progress of our country. If the present female trainees or the future teachers get awareness on social issues, they can impart this awareness to the female students. If the female students get sensitized about their human rights, violation of rights could be avoided and if at all any violation, they can raise their voice to protect them from any injustice done to them. It is essential that every citizen of India, especially every woman must have aw areness about the constitutional and legal rights.

\section{REFERENCES}

Melak, A. \& Singh,S. (2018). Factors affecting academic performance of women in engineering education and their experience of participation in employment: Literature review. International Journal of Research, 5 (1).

Aggarwal, B. (1985). Work participation of rural women in third world: Some data and conceptual biases. Economic and Political Weekly, 20, Nos. 51-52, 21.

Agarwal Vimda (1994).Stress and multiple role of women. The Indian Journal of Social Sciences,7, Nos. 3 and 4.

Agnes Folia (1992). Protected women against violence. Review of Decade of Legislation, Economic and Political weekly, (1980-89), 25, PP.19.

Ahlaw at, N. (1995). Women organizations \& social net works. New Delhi: Raw at Publication.

Andal, N. (2002). Women and Indian society.New Delhi: Raw at Publications.

Bardhan, K. (1985). Women's work, welfare and status: Forces of tradition and change in India. Economic and Political Weekly, 20(50, 51-52): 2207-20 and 2261-69.

Beteille, A. (1969). Social inequality. Penguin Books: Harmondsworth.

Beteille, Andre (1974). Studies in Agrarian social structure. Delhi: Oxford University Press.

Bhaw mick, P.K. (2002). Man and life. Journal of Social Research and Applied Anthropology, 28, (3-4), Lok Town Kolkata, July-Dec. 2002.

Blumberg, R. L. (1975). Economic influences on female status and fertility. Paper presented at the annual Meeting of the American Association for the advancement of science. New York City. January, 27.

Bose Ashish (2001). Fighting female foeticide. Economic E Political Weekly, Sept. 8.

Bose Ashish (2011). Analysis on 2001 census. The Tribune, 22nd May, Chandigarh.

Chanana, K. 1988). Socialization, education and women, explorations in gender identity. New Delhi : Orient Longmans. 
Chand Pramod (1997). Impact of 73rd amendment on women Panchayati Raj Leadership in Haryana: A Study of panchayat samities of thanesar subdivision, district Kurukshetra. Unpublished M.Phil. Dissertation, Department of Political Science, K.U. Kurukehtra.

Charton, S.E.M. (1984). Women in third world development. London: Westview Press.

Desai, N. \& Krishan Raj, M. (1987). Women society in India, Delhi. Ajanta Publications.

Gould, H. A. (1966). The Village Community from Munro to Maine. Contributions to Indian Sociology, IX:67-89. Government of India (2001a). Women and men in India 2000. Central Statistical Organisation, Ministry of Statistics and Programme Implementation. New Delhi: Government of India.

Gupta,A., (1971). The Problems of w orking w omen. Yojana, 14 (485).

Jhunjhunwala, B. \& Madhu Jhunjhunwala (2004). Indian approach to women's empowerment. Jaipur and New Delhi: Raw at Publications.

Joshi (1999). Women and development - Changing scenario. New Delhi: Mittal Publications.

Kuppuswamy, B. (1975). Social change in India, Delhi. Vikash Publishing House.

Naseema, C., (2008). Human rights education. New Delhi: Shipra Puplications, PP. 63-65.

Prasad, J. (2004). Rhetoric of human right provisions: The case of dalit women. Guru Nanagk Journal of Sociology, $25(1)$.

Parveen,S. (2007). Gender awareness of rural women in Bangladesh. Journal of International Women's Studies, 9 (1).

Vohra, R. \& Sen, Arun, K. (1985). Status education and problems of Indian women. Akshat Publication.

Zubairu,U.M., Dauda ,C.K., Paiko,I.I. \& Sakariyau,O.B. (2017). Religiosity and moral competence: A study of malaysia's accounting students. International Journal of Educational Research Review,2 (1).

Zollinger \& Smock (1977). Women: Roles and status in eight countries. New York: A Wiley Interscience Publication. 